\title{
Os desaparecidos, os fantasmas e o corpo como arquivo: o conflito sírio na dança- teatro contemporânea
}

\author{
SILVIA ALEXANDRA RAPOSO \\ Universidade Nova de Lisboa, Lisboa, Portugal
}

DOI 10.11606/issn.2316-9133.v27i1p132-170

resumo $\mathrm{O}$ presente artigo propõe uma análise da dança teatral partindo do binómio performance/política no qual se perspectiva o corpo como lugar privilegiado para a análise do poder, uma vez que um corpo ao dançar posiciona-se sempre politicamente. Para tal, procura-se contextualizar a dança-teatro dos espetáculo Antes que matem os elefantes, da Companhia Olga Roriz, e Eu Sou Mediterrâneo, da Companhia Vidas de A a Z, no seu percurso artístico e analisar as suas linguagens coreográficas e cénicas tendo em vista uma compreensão do corpo que dança como um corpo que sofre as ações das relações de poder, analisando-o como um lugar de tensão e embates que desenvolve articulações com a memória e esquecimento num jogo sensório-corporal, falando-se do corpo como arquivo e como lugar de memória e resistência e perspectivando-o como um lugar privilegiado para a análise do poder.

Palavras-chave performance, memória, guerra civil síria.

The missing, the ghosts and the body as archive: Syrian conflict in contemporary dance-theatre

abstract This article proposes an analysis of theatrical dance from the performance/politics binominal in which the body is seen as a privileged place to the analysis of power, since a body when dancing always position itself politically. To do this, we try to contextualize the dance-theatre of of the shows Antes que Matem os elefantes, by Companhia Olga Roriz and Eu Sou Mediterrâneo, by Companhia Vidas de A a Z, in their artistic course and analyse their cerographical and scenic languages having in view an understanding of the body that dances as a body that undergoes the actions of power relations, analysing it as a place of tension and clashes that develops articulations with memory and forgetfulness in a sensory-corporal game, speaking of the body as a archive and as a place of memory and resistance and look at it as a privileged place for the analysis of power.

Keywords: performance; memory; Syrian civil war. 


\section{Introdução}

Damasco mede o tempo não pelos seus dias e meses e anos, mas pelos Impérios que viu crescer, prosperar e desintegrarem-se em ruínas (Twain apudChagas, 2014).

De que modo se performa um lugar? O que revelam as performances situadas acerca do chão que habitam? De que modo o chão da performance pode refletir o mundo social ou constituir-se como contra-lugar? Que chão é este em que os artistas dançam/interpretam? Em que chão querem dançar/interpretar? E que matérias-fantasma brotam deste chão? De modo a responder a estas questões analisam-se dois estudos de caso que considerei representativos de uma abordagem artística ao Jihadismo global e à Guerra Civil Síria (2011 - presente), nomeadamente, os espectáculos: Eu Sou Mediterrâneo: um espectáculo sobre a banalidade do mal, da Companhia Vidas de A a Z, que estreou a 2 de Junho de 2016 no Teatro Turim, em Benfica (Lisboa), e passa por uma abordagem ao fenómeno do Jihadismo Global e à Guerra Civil Síria através do teatro; e o espetáculo Antes que matem os Elefantes da Companhia Olga Roriz, que esteve em cena de 15 a 16 de Julho de 2016 no Teatro Camões, no Parque das Nações (Lisboa), onde também é feita uma abordagem à Guerra Civil Síria (2011 - presente) através da dança. A etnografia resulta de uma investigação de cerca de dois anos, onde se cruzou a investigação etnográfica com a história das companhias e as biografias pessoais dos intérpretes através da pesquisa documental, testemunhos orais (conversas informais com os interlocutores), testemunhos escritos (nove testemunhos por escrito dos artistas/intérpretes e cinco notas por parte da encenação), entrevista etnográfica (cinco entrevistas, duas destas em grupo) e um processo de pesquisa no terreno que teve início com o acompanhamento dos ensaios no estúdio, nos teatros e nos bastidores.

A partir dos estudos de caso pretende-se compreender o modo como a partir do espaço da performance se abre um espaço de negociação de significados e mnemónicas associadas aos objetos e lugares de memória coletiva do conflito sírio, que procura articular uma memória coletiva de experiências traumáticas com a prática artística, transformando a cena num «museu vivo» de uma memória coletiva e mediática da Guerra Civil Síria, tendo em vista a resistência subalterna e agência cultural. Neste sentido, dentro do binómio performance/política, os estudos de caso permitiram-me perspectivar o corpo como lugar privilegiado para a análise do poder, no sentido em que este sofre sempre as 
acções das relações de poder, transformando-se num lugar de tensão e embates. Deste modo, proporcionam-nos uma leitura do corpo como veículo de contestação por quem ousa criticar e propor novas formas de se relacionar com o mundo.

\section{A primavera por florir - uma performance do drama social sírio}

É relevante compreender que a noção de coreografia ou encenação geralmente se baseia numa fantasia de que o chão da dança ou da performance é um espaço em branco, liso, sendo que na maioria das vezes se ignora a violência contida no ato de neutralizar um espaço. A principal condição para a dança ou a representação acontecerem não é o corpo, o movimento ou a música e cenografia, mas sim, como sugere Lepecki, a «terraplanagem», o alisamento prévio do chão onde esta tomará forma. Para que uma performance aconteça sem tropeções é necessário um chão liso, calcado e recalcado (LEPECKI, 2013), uma vez que o som que anima e precede a dança, o movimento, não é o canto dos pássaros, mas as convulsões da história na superfície da terra, ou seja, cicatrizes de historicidade: "a barulheira infernal da maquinaria pesada, o palavrar ou as canções de trabalho dos operários, o chincalhar das ferramentas, o vociferar e os comandos de topógrafos, engenheiros e capatazes. E também, os gritos dos escravos" (LEPECKI, 2013, p.113).

O intérprete só deveria entrar em cena após o chão se tornar liso, para que a sua atuação não tenha de negociar com os acidentes de percurso. Contudo, a performance contemporânea tem vindo a desenvolver uma relação com esse chão supostamente neutro, propondo uma arqueologia da violência que faça tropeçar o intérprete apesar de todos os alisamentos, sendo esse tropeço o símbolo do encontro com a historicidade do chão onde se dança ou interpreta. Trata-se de pensar planos de composição para uma "política do chão” (LEPECKI, 2013).

Quando se fala em "política do chão" na performance sugere-se um plano de composição que se enlaça entre o corpo e o lugar, nos seus interstícios. O chão surge como um lugar de força, transitório, liso. Um contra-lugar entre o corpo e o lugar (Vier Munhoz, 2015) ${ }^{1}$. Precisamente entre o corpo e o lugar encontramos o chão. Um espaço que esconde armadilhas para os corpos que não se submetam ao movimento imposto pelo território.

\footnotetext{
${ }^{1}$ Michel Foucault salienta em Of Other Spaces (1984) que o nosso corpo encontra-se sempre noutro lugar ao mesmo tempo que está ligado a todos os lugares do mundo, encontrando-se num lugar que é o além do mundo. Se pensarmos na performance, representar ou interpretar na dança não é apenas adquirir outro corpo, mas é fazer entrar o corpo em comunicação com forças invisíveis, é colocar o corpo noutro espaço, num lugar do contra-lugar ou da heterotopia, um espaço real onde é possível sobrepor vários espaços de sítios que por si só seriam incompatíveis (Foucault, 1984).
} 
Mas, como nos recorda Deleuze, o chão pode ser estriado como ter a lisura de um deserto (Vier Munhoz, 2015), sendo que o espaço liso é habitado por uma multidão de intensidades: "O que ocupa o espaço liso são as intensidades, os ventos, os ruídos, as forças e as qualidades tácteis e sonoras, como no deserto, na estepe ou no gelo" (DELEUZE; GUATTARI, 1997, p. 185 apud VIER MUNHOZ, 2015).

O corpo enquanto gesto dançante ou interpretado é pensado nesse chão liso. É a lisura aquilo que permite que o movimento aconteça, deslize, contraia, retraia ou até mesmo recuse a ocupar o espaço. Mas todo o chão liso está imbuído de cicatrizes através das quais podemos escorregar e tropeçar. Por esse motivo, Deleuze e Guattari argumentam que os dois espaços não existem um sem o outro: o espaço liso é constantemente convertido num espaço estriado e o espaço estriado é constantemente devolvido a um espaço liso (VIER MUNHOZ, 2015).

É precisamente a forma com que nos relacionamos com o espaço que determina o modo como o produzimos (VIER MUNHOZ, 2015). O corpo na sua relação com o chão efectua uma forma específica de movimento e neste sentido Paul Carter refere-se ao conceito de "política do chão":

Para Carter, a política do chão não é mais do que isto: um atentar agudo às particularidades físicas de todos os elementos de uma situação, sabendo que essas particularidades se co-formatam num plano de composição entre corpo e chão chamado história" (LEPECKY, 2011, p.47).

Neste sentido, dançar ou deslocar-se pelas cicatrizes que se abrem no chão e transitar pelos espaços lisos, movimentar-nos por relações intransitivas entre o corpo e o lugar é um gesto de resistência à ordem das coisas (VIER MUNHOZ, 2015). Posto isto, no sentido de esclarecer estas cicatrizes que surgem no chão liso e compreender as particularidades de uma «política do chão», saliento a noção de "haunting" associada ao conceito de "matériasfantasma" (GORDON, 1997), evocada por Avery Gordon, a que irei voltar mais adiante:

[Falar de assombrações é falar em milhares de fantasmas]; Quando sociedades inteiras ficam assombradas por atos terríveis que ocorrem sistematicamente e são simultaneamente negados por todos os órgãos públicos do governo e comunicação; Quando todo o propósito da negação verbal é garantir que todos saibam o suficiente para assustar a 
normalização no sentido de causar um estado de cansaço nervoso; Quando há fantasmas inocentes e fantasmas malévolos que vivem em bairros; Quando toda a situação clama pela inteligência distinguindo entre a verdade e a mentira, entre o que é conhecido e o que é desconhecido, entre o real e o impensável e, no entanto, é o que é precisamente impossível; Quando as pessoas que conhecemos ou amamos estão lá num minuto e desaparecem no próximo; Quando as palavras e as coisas familiares se transmutam nas mais sinistras armas e significados; Quando um prédio comum pelo qual passamos todos os dias abriga uma fachada que separa o grito das suas atividades terroristas da fala silenciosa de terríveis conversas; Quando toda a vida se tornou tão envolvida no trânsito dos mortos e dos mortos-vivos... Abordar, muito menos estabelecer, uma compreensão firme dessa realidade social pode fazer-nos sentir como se estivéssemos a carregar o peso do mundo aos nossos ombros. Simplesmente não pode ser carregado com delicadeza, um requisito rigoroso nestas circunstâncias. (GORDON, 1997, p. 64 - tradução minha).

André Lepecki reivindica o conceito de «matérias-fantasma» (GORDON, 1997) para criar uma "política do chão", sendo que na sua aceção, as "matérias-fantasma" são:

todos aqueles fins que ainda não terminaram (...), o fim da escravatura que não terminou com a escravidão; o fim da colônia que não terminou com o colonialismo; a morte de um ente querido que não apaga a sua presença; o fim de uma guerra que não deixou de ser ainda perpetrada” (LEPECKI, 2013, p.114).

A virtualidade do fantasma está em atuar como contemporâneo do presente, mas as matérias-fantasma são também todos os "corpos impropriamente enterrados da história" (LECPECKI, 2013, p.114; GORDON, 1997), ou seja, os corpos que foram negligenciados, enterrados, descartados e esquecidos pela história no espaço mais neutro, no terreno mais liso que agora brotam do chão provocando desequilíbrios e quedas e transformando esses espaços lisos num terreno difícil de dançar ou movimentar. Quero com isto referir que, para além da intencionalidade coreográfica, por vezes esses terrenos lisos expulsam "matérias-fantasma" obrigando-a a escorregar e a romper com a ilusão da neutralidade do espaço e do nosso corpo e movimento no mesmo (LEPECKI, 2013; GORDON, 1997). 
Uma política cénica ou coreográfica do chão corresponderia à forma como a encenação determina o modo como os intérpretes fincam os pés nos chãos que os sustentam e como os chãos sustentam diferentes posicionamentos e historicidades transformando-as e transformando-se (LEPECKI, 2011). Os estudos de caso que me proponho a analisar posicionam-se precisamente num chão por onde irrompem inúmeras "matérias-fantasma” e, neste sentido, procurar-se-á uma compreensão do espaço cénico como "lugar de memória" (NORA, 1984) e chão por onde irrompe as «assombrações» e os “desaparecidos” (GORDON, 1997) associados à Guerra Civil Síria e ao Jihadismo Global.

\section{Estudo de caso 1: Antes que matem os elefantes}

O espectáculo Antes que matem os elefantes subiu à cena a 15 e 16 de julho de 2016 no Teatro Camões, em Lisboa, e procura ser um alerta para uma reflexão coletiva sobre o conflito na Síria. O espectáculo havia estreado a 29 de Abril, em Aveiro, no Centro Cultural de Ílhavo, tendo como temas centrais os refugiados, as migrações e a guerra ${ }^{2}$. Os bailarinos, Beatriz Dias, Carla Ribeiro, Francisco Rolo, Marta Lobato Faria, André de Campos, Bruno Alexandre e Bruno Alves dão corpo a um grupo de pessoas que procuram um lugar e corporizam emoções, memórias, medos e inseguranças relacionadas com as migrações forçadas. E embora o espectáculo incida sobre a temática do conflito sírio, a história do espectáculo é sobre um grupo de pessoas que procuravam um lugar porque neste mundo já não existia um lugar seguro para viver. O espectáculo inicia-se com testemunhos de crianças acerca do conflito sírio, sendo que de repente a luz sobe sobre a cena distinguindo um apartamento em ruínas e uma reprodução da própria teia de iluminação do teatro caída em desequilíbrio, destruída. Uma explosão. Há pó no ar e pedras no chão. Ao fundo, no maple carmesim um homem olha o vazio, um frigorífico destruído e um corpo em espasmos entre cobertores rasgados e colchões sujos. Surgem vultos, o ambiente é pesado, apenas interrompido pelo barulho ritmado de pedras atiradas para o chão por um indivíduo. A imagem é de um apartamento-abrigo em Alepo esventrado por ciclos de violência e silêncio dramático, pessoas deambulam pelos escombros, cambaleantes e assustadas guiadas pela luz de uma lanterna e tropeçando em corpos amontoados como objectos descartáveis. No meio deste ambiente um casal tenta abraçar-se, homens

\footnotetext{
${ }^{2}$ Com direcção de Olga Roriz, seleção musical de Olga Roriz e João Rapozo, figurinos de Olga Roriz e Paulo Reis, desenho de luz de Cristina da Piedade e produção de áudio de João Rapozo.
} 
carregam pedras em alguidares e mulheres lavam o cabelo simbolizando toda a normalidade, dignidade e controlo que resta sobre o corpo. Os bailarinos atiram-se ao chão, coberto de pedras, até que Bruno Alves, um dos bailarinos, agarrando num balde cheio de pedras, o despeja sobre si como se o tecto desabasse, pedras estas que são recolhidas posteriormente por Bruno Alexandre que as utiliza como material de reconstrução da cidade. A música retira-se para o fundo, os destroços e as acções permanecem e o espectáculo termina como se voltasse ao início, não procurando uma resolução, mas indicando que o flagelo continuará.

\section{Estudo de caso 2: Eu Sou Mediterrâneo}

Já o espectáculo Eu Sou Mediterrâneo subiu à cena a 2 de junho de 2016 no Teatro Turim, em Benfica (Lisboa), passando por uma abordagem ao fenómeno do Jihadismo Global e da Guerra Civil Síria. Com encenação de Mónica Gomes e interpretação de Mónica Gomes, Anabela Pires, Margarida Camacho, Márcio Piósi, Filipe Lopes, Liane Bravo e Sofia Assis ${ }^{3}$, o espectáculo tem como temas centrais os conceitos de «Jihadismo Global», «violência» e «banalidade do mal», procurando problematizar a relação entre guerra, política, violência e poder. O espectáculo tem início com uma voz-off que evoca uma referência à morte e à guerra. Segue-se a entrada de $\mathrm{O}$ Coro, uma figura hermafrodita que personifica a liderança enquanto voz do poder acompanhado pela figura da Morte, ao centro, carregando sacas de sarapilheira que empilha no lado esquerdo da cena formando uma trincheira. Durante o transporte das sacas os corpos que as transportavam caiem mortos em tiroteio. A figura do Coro assume a rigidez de uma placa que também segura entre as mãos. A placa, composta por seis setas de direção permite situar a ação: "Museu Vivo Guerra Síria”, "Rádio Medo FM” e "Drogaria D. Intolerância”, “O Terrorista serviços aéreos”, "Hospedaria Mediterrâneo" e "FOME Snack-bar”. Abre a luz para o lado direito do palco e vislumbra-se uma figura feminina, a Louca, em cima de um pedestal, de punhos cerrados em posição estátua que comenta a ação e narra o início da história de Hasan Al-Phortugali, um soldado jihadista que desertou. O soldado Hasan irrompe então pela cena acompanhado da figura da morte e continua a narrar a história da sua chegada à guerra na relação com o colega Abdul, um soldado morto (personagem fantasma) que

\footnotetext{
${ }^{3}$ Com criação de texto dramático de Sílvia Raposo e Mónica Gomes, criação e seleção de figurinos de Helena Raposo, desenho de luz de Mónica Gomes e Miguel Cruz, cenografia de Mónica Gomes e Helena Raposo, coreografia de Margarida Camacho, composição musical de Ivo Soares.
} 
também ingressou as fileiras. A Louca volta a intervir trazendo à discussão a "Pedra de Meca" e o soldado segue a narração, falando agora de Zhaida, uma mulher com quem se cruzou na Turquia e que o levou a desertar, até que a Louca volta a intervir para comentar o conflito na síria, o que o leva a narrar a história de Razi, um menino palestiniano que foi morto na Faixa de Gaza e cujos destroços humanos foram projectados para Israel, sendo que todos os meses Aziza, a mãe de Razi, deslocava-se a Israel para recolher partes dos destroços da criança para poder realizar um funeral. A Louca intervém novamente questionando o modo como um corpo morto se pode transformar num cadáver histórico. A ação volta-se novamente para o soldado que, agora enforcado em cima do banco, está morto. Há um blackout e tem início uma partitura sonora onde os vários intérpretes vociferam sons de guerra, como se fossem crianças: uma hélice de helicóptero, sons de granadas, alguém que grita ao longe, um corpo que se move no espaço, uma respiração ofegante... Faz-se silêncio. A Louca desloca-se para junto da placa de direções assumindo a posição do Coro. Os corpos começam a dançar. As mulheres juntam-se numa reza. Há um corpo que se autoflagela, um outro que oprime e se liberta. Ao longo da partitura é projetado um vídeo evocando o fascínio mediático pela performance da violência associada à figura do terrorista e do refugiado. Durante esta partitura, a actriz que interpreta a figura do soldado, despe o colete à prova de balas assumindo-se enquanto o Homem, abandonando o papel que representava e, no centro do palco, apela ao combate à banalidade do mal.

\section{A improvisação como caminho para uma política do chão}

O corpo na dança apresenta-se construído de forma diferente consoante o momento histórico em que se insere. $\mathrm{O}$ ato de dançar, destaca Maria José Fazenda, "é indissociável das técnicas corporais através das quais o corpo e o seu movimento se constroem formal e significativamente, pelo que a atuação do corpo na dança não é um fenómeno natural" (FAZENDA, 1996, p.141). Mas apesar desta constatação, a história da dança teatral ocidental, particularmente a americana do século XX, é marcada por ideia de “corpo natural”, associada ao trabalho de Isadora Duncan no final do século XIX e de Steve Paxton, nos anos 70, cuja prática artística consistiu na exploração de um "movimento natural" (FAZENDA, 1996) ${ }^{4}$ enquanto forma de insurgência contra o elitismo dominante

\footnotetext{
${ }^{4}$ Se até à primeira década do séc. XX o ballet dominava a dança teatral ocidental, Isadora Duncan insurgese contra a mistificação, descorporização e artificialismo da dança clássica e cria uma "Nova Dança" assente na descoberta de um "corpo natural" (Fazenda, 1996: 142). Neste sentido, assiste-se a uma ruptura
} 
do ballet. Rompendo com um paradigma de a-historicidade, a "nova dança” propunha uma "política do chão"5 (LEPECKI, 2013).

Também marcada por este retorno ao chão, na Europa dos anos 60, paralelamente aos pós-modernos americanos, uma coreógrafa contemporânea, não associada à Nova Dança, recupera o legado da dança expressionista alemã que vem a consolidar na DançaTeatro. A coreógrafa alemã Pina Bausch cria, assim, a sua tanztheater, uma corrente de dança que redefiniu a dança contemporânea a partir de 1980 (GREBLER, 2010) e que desenvolve alguns conceitos do Drama Épico de Brecht ${ }^{6}$. Posto isto, visando questionar o mundo através da linguagem híbrida do teatro e da dança, Bausch apresenta-nos corpos carregados de memórias, nos quais os bailarinos recriam experiências pessoais, uma vez que as coreografias advinham de improvisações baseadas nas suas histórias e narrativas pessoais. Neste sentido, a representação da identidade e alteridade no trabalho de Pina resulta de um processo de narração de si próprio que permite que os bailarinos construam novos olhares sobre as suas próprias experiências (ARAÚJO, 2015).

Por conseguinte, partindo desta viragem na história da dança analisa-se a prática de improvisação enquanto instrumento de criação artística nos estudos de caso em análise, uma vez que, no caso da companhia Olga Roriz, não só a dança apresenta necessidade de discursar sobre si própria e de teatralizar e verbalizar o seu corpo e movimento (BUCCHIERI, 2011), mas também, no caso da companhia Vidas de A a Z, o teatro contemporâneo, para além de já não se resignar à tradição dramática ocidental, que privilegia uma hierarquia onde a palavra reside no topo e o corpo na base, deixa cada vez mais "de ter na palavra o seu lugar principal e encontra, também no corpo - um «corpo

com a tradição a partir de uma recuperação da «naturalidade» do corpo (Fazenda, 1996), conceção que viria a influenciar o "contact improvisation", um estilo dança que nasce de um grupo de coreógrafos e bailarinos cuja postura propunha levar a dança a outros locais que não os teatros tradicionais e questionar as divisões entre o espectador e o performer, utilização de pessoas não treinada para além de bailarinos, rejeição da organização social das companhias de dança, bem como da diferenciação social dos sexos, introduzindo gestos e ações realizados no quotidiano, etc. (FAZENDA, 1996, p.145).

${ }^{5}$ Entenda-se o termo por "um encontro aberto e relacional com a historicidade do chão onde se dança (...), uma dança aberta para aceitar e experimentar com os efeitos cinéticos das matérias-fantasmas, que interrompem a ilusão de uma dupla neutralidade, a do espaço e a do nosso movimento nele" (LEPECKI, 2013, p.114-115).

${ }^{6}$ Desenvolvendo alguns conceitos do Drama Épico de Bertolt Brecht, Bausch assume um compromisso políticoideológico, pautando o seu trabalho a partir de temas que aludem à condição sócio-política do homem contemporâneo. Entendendo o corpo individual como também um corpo colectivo, inscrito em inúmeras relações de poder, a coreógrafa procurou problematizar a capacidade do corpo em expor os condicionamentos da sociedade, explorando o conceito brechtiano através da teatralidade, em vez do comum movimento codificado (GREBLER, 2010). Pretendia, neste sentido, explorar o movimento para além da técnica da dança e por isso Bausch fez uso do repertório processual teatral para criar novas técnicas e refazer conceitos coreográficos. A repetição obsessiva e a tecnicização dos gestos quotidianos irrompem como uma estratégia que visa o efeito de distanciamento, fornecendo o tempo ao espectador para que ele no que está a ver (GREBLER, 2010, p.6), no sentido em que "as pedras de um muro derrubado tornam o passo difícil e inseguro. Quando se traz para dentro do teatro algo que em geral se encontra fora, faz-se apelo ao olhar" (BAUSCH, 2000, p.12). 
interessante» - os seus caminhos dramatúrgicos” (BUCCHIERI, 2011, p.62). Evidenciase, deste modo, uma compreensão do corpo em teatro como caminho para meditações estéticas quando o corpo na dança já não é um mero instrumento a ser utilizado, mas também um lugar de intervenção (BUCCHIERI, 2011).

Neste sentido, resgatando o conceito de "discurso oculto" (SCOTT, 2000), a improvisação poder-se-á, deste modo, inserir na concepção de uma "arte da resistência", tal como aferiu James Scott, no sentido da criatividade cultural no domínio dos formatos de resistência subalterna, remetendo para a prática e para as "maneiras de fazer" (ALMEIDA, 2014: 101). Seja de Isadora Duncan, passando pelo expressionismo alemão, à dança-teatro de Pina Bausch o regresso à «política do chão» caracteriza-se por uma recuperação da criatividade no que diz respeito aos formatos de resistência, aliados ao que Sílvia Pinto Coelho denomina por «dançar-pensar» enquanto reivindicação do pensamento na dança (PINTO COELHO, 2010).

É precisamente no contexto desta reivindicação que analiso os estudos de caso, dado que tanto Olga Roriz, como Mónica Gomes produzem imagens através do discurso dançado, sendo essas imagens de pensamento, dúvida, de posturas corporais, expressões gestuais e corporais:

Já trabalho assim desde 94 e porque é que eu comecei a trabalhar assim? Porque eu trabalhava na Gulbenkian ou por outra, na Companhia do Reportório e onde obviamente que não pedia a ninguém para improvisar. Fazia os meus movimentos e eles copiavam. Era um estilo mais mimético. Mas depois, ao mesmo tempo desde 88 , eu comecei a fazer os meus solos, e pronto, quando eu comecei a fazer os meus solos, eu comecei a perceber que havia um método de improvisação do intérprete. Eu estando de fora para dentro, não é? Um método de improvisação que eu gostaria de conseguir passar porque é complicado, é muito difícil (Entrevista a Olga Roriz, 2016).

A própria interpretação, na maioria dos casos, resulta de uma estratégia de improvisação (Entrevista a Mónica Gomes, 2017).

A improvisação irrompe enquanto possibilidade de pensamento. As ações são interrompidas pela reflexão e, de acordo com Pinto Coelho, toda a percepção já se constitui enquanto ação de pensar, no sentido em que o corpo está sempre a pensar e, por isso, a improvisação insurge-se como pensamento e resposta a uma forma de dança que leva a 
automatismos (PINTO COELHO, 2010). Destaca-nos o bailarino André de Campos a respeito do método de improvisação na construção do espetáculo Antes que matem os elefantes:

Há mais liberdade, há mais responsabilidade...Tudo aquilo que nós fazemos é mais pensado, tem mais carga, tem mais peso, e nós podemos também, ao fim ao cabo, fazer uma experimentação de tudo aquilo que não é interessante, tanto para nós como para a Olga, e filtrar...E ir filtrando, que é o momento em que conseguimos lá chegar (Entrevista a André de Campos, 2016).

A dança, bem como a coreografia, é aqui entendida enquanto pensamento, discurso e meio de investigação de si próprio, uma vez que, como destaca a coreógrafa Olga Roriz e a intérprete Margarida Camacho:

A improvisação é uma coisa que tu tens de saber ir buscar às tuas memórias, às tuas vivências...É uma coisa complicada, não é nada fácil, é complicado, exige imenso e é uma coisa "non-stop". Por exemplo, se um bailarino trabalha com o método mimético, tu chegas aqui, podes dar o litro, estás aqui até às seis da tarde e suas, não é? E depois vais-te embora, vais para casa e não ficou nada. Se tu trabalhas o método de improvisação, o rasto vai até casa, vai até tu adormeceres, acordas a pensar naquilo...Não tem nada haver, é um outro envolvimento muito, muito, muito diferente... (Entrevista a Olga Roriz, 2016).

Eu acho que a dança é uma forma de meditação, uma forma de nos acalmar, nos mudar e também de pensar. De pensar o que é que nós próprios podemos fazer para ajudar as pessoas (...). Eu quero através da dança dizer «eu estou aqui e que sirva para mudar alguma coisa» (Entrevista a Margarida Camacho, 2016).

Este envolvimento diferente prende-se com a posicionalidade que emerge do movimento, ou seja, a qualidade de o intérprete se colocar dentro de qualquer processo (Pinto Coelho, 2010: 91) enquanto forma emancipatória e política de colocar o corpo em situação. A possibilidade de dançar-pensar traduz-se pela «improvisação» como método, ou seja, pelo modo como o corpo se relaciona com o espaço e com o tempo e o tipo de perceção e memória que desta relação advém ou que permite evocar (PINTO COELHO, 
2010). O estúdio de ensaio assume-se enquanto «casa-espelho», "uma espécie de «máquina de reflexão», um laboratório de testar, ou de ensaiar potências" (PINTO COELHO, 2010: 105), tal como evidencia Roriz:

Eu preparava o cenário, antes de se preparar o cenário, juntávamo-nos e eu dizia-lhes qual era o ponto de partida daquela improvisação, daquela sessão. Às vezes era só uma palavra como condenação...Podia ser violência exterior, podia ser interajuda, podia ser outra coisa. Às vezes também lhes pedia a eles...Isso eu pedi. Pedi logo no princípio palavraschaves sobre este tema, guardei-as e, de vez em quando, lançava para cada um deles palavras-chave (Entrevista a Olga Roriz, 2016).

Ainda, para o bailarino Francisco Rolo, a ideia da mobilização grupal ou da formação da communitas (TURNER, 1974) surge associada a uma estratégia que permite potenciar a "casa-espelho" como prática de produzir encontros e relações que opera enquanto máquina de pensar (PINTO COELHO, 2010):

E depois há outra coisa, que eu também acho muito importante e que acho que a improvisação permite muito, é a questão do grupo...A improvisação fez-nos unir bastante enquanto grupo, enquanto sete pessoas juntas num espaço, e depois também o facto de haverem...Ou seja, são sete pessoas que estão a improvisar, são sete pessoas que estão constantemente a pôr ideias para o espaço, não é? (Entrevista a Francisco Rolo, 2016).

Ainda, a improvisação é uma linguagem que permite ao intérprete alcançar uma zona liminar (TURNER, 1974). O ato de improvisar é tido em conta como um território de passagem (VAN GENNEP, 1978) entre o processo de improvisação e a obra final, uma vez que a improvisação se transforma na própria obra. O intérprete encontra-se, assim, numa situação de liminaridade e é esta característica liminar o que acentua o lugar da improvisação como espaço de resistência cultural, social e política (TURNER, 1974). Destaca-nos Mónica Gomes a propósito do processo de improvisação no espetáculo $E u$ Sou Mediterrâneo:

O que há de íntimo no espectáculo é precisamente aquilo que é improvisado, o que acontece entre aquilo que é proposto e a acção que se concretiza.Ou seja, em última instância, aquilo que faz com que nos 
relacionemos de uma forma mais íntima com o personagem ou com um espectáculo é precisamente as zonas de fronteira, ou antes, o trabalho criativo do intérprete é a alma da criação e esse é um trabalho que é improvisado, não tem como ser de outra forma e, mesmo depois de fixada a improvisação, há sempre um espaço fronteiriço, daí que em teatro todos os dias sejam diferentes, caso contrário seríamos autómatos (Entrevista a Mónica Gomes, 2017).

Evidencia-se uma compreensão das dimensões políticas possibilitadas pela improvisação, destacando-se as posturas dos intérpretes/encenadora/coreógrafa nos processos de composição em tempo real:

A improvisação foi uma forma de fugir à estrutura porque quando começámos não sabíamos onde é que íamos dar e também não importava muito se o resultado ia servir estruturalmente para integrar o espectáculo ou não. Estávamos à procura de outra coisa, (...) de uma forma de tornar a história nossa, fazê-la passar de forma mais íntima pelos nossos sentidos e emoções (Entrevista a Monica Gomes, 2017).

Estabelece-se, neste sentido, uma relação entre improvisação e posicionamento político do sujeito, uma vez que a própria forma de lidar com as questões sócio-político-culturais são inerentes ao sujeito dançante, tal como nos destaca o bailarino André de Campos a respeito do seu processo de trabalho em Antes que matem os elefantes.

Em termos de improvisação, dá-nos uma liberdade total. De repente, ali nós podemos fazer tudo aquilo o que «quisermos» (...). Nós tivemos muita liberdade, como sempre, e eu acho que a Olga confia muito em nós em relação a esse aspecto, nós conseguimos agarrar na nossa interpretação, não enquanto bailarinos, mas enquanto pessoas, e na nossa opinião pessoal e na nossa pesquisa pessoal levá-la para estúdio (Entrevista a André de Campos, 2016).

Trata-se aqui de um entendimento específico da improvisação enquanto formato de “discurso oculto" tornado público (SCOTT, 2000), servindo de método à descentralização do poder na dança, sendo que o poder simbólico relaciona-se com a improvisação enquanto lugar de problematização das estruturas sociais impostas pelo poder disciplinar, referindo-se neste caso a um "fazer-dizer oculto" (SETENTA, 2007; SCOTT, 2000) que 
visa propor soluções e derrubar estruturas, assumindo a improvisação como um ato de resistência. Destacam-nos as bailarinas/intérpretes Beatriz Dias e Margarida Camacho:

Há coisas que são muito genuínas no processo de improvisação e provavelmente nós não sentiríamos vontade ou não aconteceriam se fosse uma coisa que a Olga pedisse coreograficamente ou se nos impusesse isso. Eu acho que uma das coisas boas da improvisação é (...) surgirem coisas do nada (...) e criar este tipo de relações (...) comigo própria. Eventualmente não suscitaria tanta emoção e essa espontaneidade se fosse por outro método porque haveria uma regra, haveria um plano para aquilo acontecer e iria ser difícil ir a esses sítios (Entrevista a Beatriz Dias, 2016).

Algumas partes da improvisação é também a minha forma de me revoltar contra as regras. Eu acho que nós somos sempre revoltados e cada vez que eu vou sabendo mais sobre este tipo de assunto que estamos a tratar, cada vez mais eu quero transmitir aquilo que me revolta (Entrevista a Margarida Camacho, 2016).

Os testemunhos acima permitem-nos entender a improvisação enquanto espaço de tomada de posição política através da descentralização do poder na dança permitido por discurso corporal não dominante - «o fazer-dizer oculto»-, que assume uma forma compartilhada de decisão e organização da criatividade. A este respeito acrescentam-nos também a coreógrafa Olga Roriz e a encenadora Mónica Gomes que

A primeira coisa que acontece é que o espectáculo é muito mais do intérprete do que se injectado nos corpos, não é? Não quer dizer que seja sempre. Por exemplo, a parte da...Como eu estava a dizer, aquelas duas partes do uníssono vieram de fora. Portanto, foram construídas a partir de mim, a partir de alguns momentos que eles estavam a tentar fazer. Pronto, mas já é uma coisa de fora para dentro. Agora depois a construção muito mais coreográfica ou teatral, digamos, é uma coisa que tem de partir deles (Entrevista a Olga Roriz, 2016).

A dada altura houve qualquer coisa que se esgotou e, nesse sentido, fui à procura de instrumentos que me permitissem criar uma narrativa comum. A improvisação surgiu neste sentido, como uma forma de nos relacionarmos enquanto equipa com as temáticas que estávamos a abordar de uma forma mais intíma, mais pessoal, que fosse para além da 
narrativa exterior mais estruturada que até então servia como fio-deprumo da encenação. Começámos a experimentar coisas sem ter definido à partida para onde é que íamos, foi uma questão depois de reflectir sobre e de eu fazer a selecção (Entrevista a Monica Gomes, 2017).

Compreende-se aqui o "fazer-dizer" da improvisação como um método que permite escapar à "tirania do conceito de sujeito isolado e essencializado, pois entende que o sujeito é feito, constituído de outros sujeitos" (SETENTA, 2007: 90). A própria noção de sujeito performativo é entendida enquanto um sujeito partilhado, reivindicando uma escolha política que defende uma forma diferente de organização do «fazer-dizer» na dança-teatro contemporânea (SETENTA, 2007), particularmente demarcada no testemunho de Olga Roriz:

[Improvisar] é complicado e realmente leva tempo e nas companhias de reportório como é Companhia Nacional, não têm tempo para parar durante três meses para eu agora fazer um espectáculo assim e, por isso, é que eu tenho a minha companhia para fazer aquilo que eu quero e bem me apetece, e os bailarinos agradecem obviamente (Entrevista a Olga Roriz, 2016).

A improvisação irrompe, deste modo, como um método de trabalho e formação do intérprete a partir do qual a coreógrafa se procura distanciar das técnicas clássicas e modernas mobilizadas no seu trabalho com a Companhia Nacional de Bailado enquanto estrutura de poder dominante. O "fazer-dizer oculto" na improvisação trata-se, assim, de uma alternativa discursiva que a coreógrafa empreendeu face a um "discurso público" veiculado pela Companhia Nacional de Bailado (SCOTT, 2000). O "fazer-dizer oculto" enquanto estratégia de descentralização do poder na dança permite, assim, sustentar micro-poderes e a autonomia do intérprete/coreógrafo. Ao assumir uma posição, o intérprete estabelece uma relação de poder no acto da improvisação, sendo que, como argumenta Chavarelli, falar de poder nos processos de criação é remeter para duas perspetivas diferentes: o poder disciplinar e o poder simbólico (CHAVARELLI, 2015). Contudo, durante os processos criativos, as relações de poder estabelecidas no ato de improvisar associam-se mais a uma ideia de poder simbólico, tal como apontado por Bourdieu, do que a processos de poder disciplinar, ou por outras palavras, estas visam muitas vezes esvaziar ou resistir ao poder disciplinar (FOUCAULT, 1987): 
O poder simbólico é, com efeito, esse poder invisível o qual só pode ser exercido com a cumplicidade daqueles que não querem saber que lhe estão sujeitos ou mesmo que o exercem (...). O poder simbólico é um poder de construcção da realidade que tende a estabelecer uma ordem gnoseológica: o sentido imediato do mundo (e, em particular, do mundo social) supõe aquilo a que Durkheim chama o conformismo lógica, quer dizer, «uma concepção homogénea do tempo, do espaço, do número, da causa, que torna possível a concordância entre as inteligências». (...) As diferentes classes e fracç̧ões de classes estão envolvidas numa luta propriamente simbólica para imporem a deifnição do mundo social mais conforme aos seus interesses, e imporem o campo das tomadas de posições ideológicas reproduzindo em forma transfigurada o campo das posições sociais. Elas podem conduzir esta luta quer directamente, nos conflitos simbólicos da vida quotidiana, quer por procuração, por meio da luta travada pelos especialistas da produção simbólica. (BOURDIEU, 1989, p.7-11).

Este tipo de poder foi caracterizado por John Thompson como o poder cultural ou simbólico, ou seja, um poder que "nasce na actividade de produção, transmissão e receção do significado das formas simbólicas" (THOMPSON, 1998, p.24), uma vez que "os indivíduos se ocupam constantemente com as atividades de expressão de si mesmos em formas simbólicas ou de interpretação das expressões usadas pelos outros” (Ibidem). O poder simbólico, enquanto manifestação dos sistemas simbólicos (religião, arte, etc.) e característica das atividades culturais, associa-se, deste modo, à relação que o intérprete e criador estabelecem com a improvisação enquanto espaço e meio de produção simbólica que permite lutar por uma hegemonia de classe e ideológica (BOURDIEU, 1989):

Há individualidade. A importância dada à estrutura é porque o próprio poder tem uma estrutura, há qualquer coisa que é improvisada que tem a ver com o caos e com o acaso quando a Margarida faz o solo dela, mas o poder tem uma estrutura efectivamente. Portanto, é a representação da estrutura da autoridade, do poder. Enquanto ela representa o acaso, que é algo imprevisto e por isso improvisado (Entrevista a Mónica Gomes, 2016).

Ela deu uma entrevista há pouco tempo em que dava o exemplo do Bruno Alves a atirar as pedras para cima dele. Isso foi uma decisão dele, 
não dela. Agora aquilo que ela fez foi: «Agora tens de fazer isso várias vezes.». Para vocês verem também que nós temos essa capacidade, esse poder, mas ela depois tem um poder por detrás da coisa bem mais pesado, não é? A Olga diz: «Achei interessante, agora faz isto desta maneira e esta quantidade de vezes» e nós temos de engolir (Entrevista a André de Campos, 2016).

O testemunho da encenadora e do bailarino trazem ainda uma outra questão no âmbito das considerações expostas relativamente ao método de improviso, pois, ainda que a improvisação se manifeste enquanto estratégia de resistência e descentralização de poderes na dança-teatro, esta parece em simultâneo funcionar como mecanismo de controlo social por parte dos coreógrafos/encenadores, uma vez que se apresenta como uma espécie de desordem dentro das regras (SCOTT, 2000). Mas embora esta questão não deva ser ignorada, ela faz parte de um espaço liminar onde é possível a coexistência de diferentes formas de poder, pois a improvisação não surge apenas enquanto uma válvula de escape que serve de mediação a possíveis situações de conflito, mas também se apresenta como um momento de antiestrutura e resistência político-cultural.

Em suma, o "discurso oculto" do corpo (SETENDA, 2007), ainda que organizado institucionalmente, possibilita o exercício da agência e resistência face à estrutura de dominação veiculadas através da improvisação, uma vez que ambas as estruturas artísticas manifestam a sua própria resistência face a uma estrutura de dominação superior e, neste sentido, procuram romper com a linguagem estabelecida e com as convenções da sua área: os encenadores/coreógrafos procuram novas linguagens no campo artístico que possam romper com as linguagens formalmente instituídas, ou seja, as premissas reconhecidas publicamente como orientadoras na dança/interpretação, procuram por modos de agir contra-hegemónicos, renegam a tirania da autoria individual, procurando por um modo de criação coletivo que resulta de ações compartilhadas entre intérpretes e produção/direção/encenação. Neste sentido, as próprias estruturas artísticas emergem como movimentos de resistência, criando novos coletivos que reivindicam proposições políticas, caminhando para uma política do chão. 


\section{Mujahidins, elefantes e fantasmas}

A memória apresenta-se como matéria fundamental de qualquer criação cénica, seja a memória associada à técnica, ao modo de fazer, a um determinado conhecimento específico, ou até a memória do performer, interpretada e expressa pelo seu corpo (ZILI; SANTOS, 2015). A própria relação entre a memória, o corpo no teatro e o corpo no quotidiano apresenta um percurso histórico reconhecido através de Constantin Stanislavski, que, no final do séc. XIX e inspirado pela psicologia experimental de Théodule Ribot, recorre à memória das emoções como parte do seu sistema de atuação que procurava, através da representação motora das experiências emocionais vividas, criar uma nova sistematização para as acções físicas do intérprete (LOPES, 2009). A partir de 1920, o Actors Studio, um conjunto de artistas de Nova Iorque, apropriam o sistema de atuação de Stanislavski e criam o conhecido "método de stanislavski", caracterizado por um enfatismo na memória emocional como método de interpretação para o ator (LOPES, 2009). Também, a partir dos anos 60 , num período marcado por revoluções políticas e novos movimentos artísticos, o teatro de Grotovski, Peter Brook e Eugenio Barba apropriam a memória como instrumento para trabalhar e pensar o corpo (LOPES, 2009). Barba coloca o foco do seu trabalho na relação do corpo com a experiência vivida, uma vez que, ao propor o reconhecimento de uma organização básica do corpo do performer entendida como pré-expressiva, ou seja, entendida num conjunto pré-cultural de reações fisiológicas universais, demonstra-nos como a partitura física é guiada pela nossa memória (BARBA, 1995). O corpo é, assim, o lugar da memória do intérprete que, no trabalho com os seus arquivos, encontra formas de materializar o que sente daquilo que recorda.

A performance cénica e o corpo entendido enquanto arquivo surgem, neste contexto, como um lugar que permite evocar a memória dos acontecimentos. Parte-se da premissa de que o estudo da relação entre o corpo, memória e performance nos revela caminhos alternativos, desvios, micropolíticas e ações de resistência face ao mundo social, à arte e ao próprio corpo, na contemporaneidade. Neste sentido, a aproximação entre os estudos da memória e a performance cénica trazem algumas questões relevantes: como pensar a memória na performance cénica quando relacionada com corpos que representam momentos históricos que não aqueles em que as coreografias/encenações foram criadas? O que significa reconstruir um acontecimento? De que modo os figurinos, cenários e sequências de movimentos colocados em cena permitem reconstruir um 
acontecimento? De que modo a memória na performance se pode constituir enquanto micro-resistência? Trata-se de um questionamento da performance cénica enquanto expressão estética que estabelece uma relação com o tempo e o espaço (CERBINO, 2009). E que tempo é este?

No caso das performances em análise, este tempo é trabalhado como um tempo imobilizado, um tempo que anseia por um desejo trágico de praticar a suspensão (PRINZAC, 2005). Fala-se aqui no tempo do drama social, demarcando-se entre o princípio e o fim, preso numa temporalidade que demora. Refere o bailarino André de Campos a respeito desta suspensão da temporalidade no espetáculo Antes que matem os elefantes:

Aquele espectáculo acho que podia começar em qualquer sítio do espectáculo. Por acaso é aquele o início, mas eu acho que podia até começar pelo fim ou começar pelo meio...De repente, alguém abre uma janela e vê aquilo (...). No meu caso eu fiz muita pesquisa antes da peça. Não só pelo que acontece na Síria, mas por várias balizas temporais em que isto aconteceu no mundo, em que houve um conflito, num determinado território, e o grupo de gente viu-se forçado a sair daquele país porque já não havia país. Primeiramente fui mais por aí porque eu quis saber porque é que isto acontece, ou de que maneira é que na Síria é diferente, ou o que é que faz com que aquilo aconteça agora, ou se aquilo é também consequência dos outros conflitos que houve, e fui por aí (Entrevista a André de Campos, 2016).

O tempo imobilizado permite também a sobreposição de diferentes tempos sociais, históricos e individuais advindos das noções e necessidades espaço-temporais dos intérpretes e coreógrafa, acentuando ainda mais o carácter liminar da temporalidade definida por Roriz:

Uma coisa que já me perguntaram era se aquilo era mesmo uma hora e cinquenta, aquele espectáculo se era aquele tempo. E eu acho que não, aquilo é muito mais tempo. (...) Há espectáculos que eu faço que passou um dia inteiro. (...) Há outros que eu faço que é naquela hora, é o que se passou naquela hora, é aquela hora mesmo real. E aqui eu acho que não (...). Mas isto depende da cabeça de cada um. Pronto, eu não digo que sejam anos, mas realmente não é um período, não é aquele período que se vê, não é um período real (Entrevista a Olga Roriz, 2016). 
A concepção do tempo dialoga aqui com a noção de tempo morto, um tempo suspenso caracterizado pela liminaridade que é assumido logo no início do processo social do drama estético - a voz-off das crianças que dá abertura ao espetáculo com uma duração de 7 min. ou a música que só tem início 20 min. depois do espetáculo começar - e que convoca uma proposição política. Este tempo morto é um tempo simbólico que procura apelar a uma mudança, uma vez que sem a morte não existiria renovação e, neste sentido, Roriz, ao introduzir uma temporalidade que dialoga com a morte, apela a uma necessidade de agência face à própria suspensão temporal de um conflito que se vê arrastado desde 2011 e afigura enquanto temática primordial do seu drama estético. Destaque-se ainda o testemunho do bailarino Francisco Rolo: "Não é porque as pessoas se sentam no teatro que aquilo vai começar. Aquilo está a acontecer e as pessoas estão lá a ver, chegam àquela altura e começam a ver" (Entrevista a Francisco Rolo, 2016).

É possível compreender como o tempo imobilizado surge como uma estratégia cénica para sustentar uma dramaturgia que tem por base o drama social e que procura no real uma forma de relação com o traumático (Fradique, 2016), tal como também nos evidencia a coreógrafa:

Imaginei uma câmara, não sei...Qualquer coisa deu-me um tempo diferente realmente, não tão manipulado. Quer dizer, ele é completamente manipulado, mas não é tão manipulado quanto isso, por isso é que o espectador fica ali um bocado: «Ai, ai, isto desemburra ou não desemburra? Desemburra.», quer dizer, está ali, é aquilo e não há música e pronto, levas com aquilo. Portanto, há ali algo de um tempo real em certos momentos, não em todos claro, que eu acho que para mim é fulcral para a construção daquele espectáculo e aquilo que eu tenho de passar para o público ou dar hipótese do público poder pensar (Entrevista a Olga Roriz, 2016).

O real toma aqui a forma de espaço liminar onde a marginalidade social, cultural ou física inverte a ordem, transformando-se num instrumento simbólico de renovação (FRADIQUE, 2016). Trata-se de uma manipulação do tempo como forma de afirmação do real enquanto suporte para chamar à cena os dramas sociais do indivíduo moderno, no sentido em que o real em cena adquire um valor político (FRADIQUE, 2016). 
Este real é aquilo a que Teresa Fradique, parafraseando Helga Frinter, denomina por um "real imanente", remetendo para a dor física e exaustão enquanto formas de autenticação e fundamento da ação performativa (FRADIQUE, 2016), o que, por sua vez, já havia sido evidenciado por Artaud e a noção de "corpo sem órgãos" (DELEUZE; GUATTARI, 2007). Olga Roriz pretendeu, deste modo, estabelecer a relação com o real através de uma violência sobre os corpos e de um tempo ritual, estendido, imobilizado e, em simultâneo, suspenso que se perde, nas palavras de Prinzac, numa "espacialização' (PRINZAC, 2005).

Esta imobilização do tempo também se encontra presente no espectáculo Eu Sou Mediterrâneo, evidenciando-se, tal como nos destaca a encenadora Mónica Gomes, através de uma continuidade entre tempo e matéria: "Existe, ainda, um banco, onde o soldado se senta e que se torna num marco temporal ao remeter para uma ideia de imobilidade, de alguém que está à espera ou de qualquer coisa que está em espera (GOMES, 2016, p.53).

O banco assume a expressão da temporalidade ao longo do espetáculo, remetendo também para um tempo em suspenso, ou seja, um tempo que não acaba e que é liminar (GENNEP, 1978; GODINHO, 2014). Este tempo liminar está presente no banco enquanto marcador espaço-temporal que representa algo pelo qual o soldado está sempre à espera mas que nunca vem, encontra-se também associado a um ritual de passagem (GENNEP, 1978) que marca o final do drama estético - a morte do soldado-, uma vez que é o banco que lhe é retirado debaixo dos pés aquando do seu enforcamento. Mas, se durante todo o espetáculo, o tempo é um tempo imobilizado, objetificado no banco de cena, durante a partitura de dança dá-se uma mudança temporal, onde o aspeto ritualizado do tempo se insurge:

Após a segunda morte do soldado existe um blackout e uma partitura sonora, na qual são reproduzidos sons associados à ideia de guerra. Estes sons reflectem parte do universo interior das personagens, mas também correspondem ao já referido renascimento do próprio espectáculo, à semelhança do recém-nascido que chora para receber o oxigénio que lhe dá a vida. Este renascimento está associado a uma mudança temporal, sublinhada no discurso da Louca - "Este é o tribunal dos tempos. E o tempo urge. Urge. O tempo.”; mas também pelas metamorfoses do soldado, do Coro e da própria figura da Louca. Os "tempos" aludem às 
vidas humanas, que têm uma duração, e o "tribunal" apela ao autojulgamento no sentido da auto-correcção, da reflexão. O recém-nascido espectáculo, tal como o processo natural da vida, parte da morte e segue o fluxo normal: nascimento, vida e morte novamente. Se o nascimento corresponde ao momento da partitura sonora, a vida corresponde à partitura de dança (...), uma partitura que procura expressar a luta da vida que, mais uma vez, culmina na morte, reconhecendo o ciclo natural da vida que assenta no constante renascimento (GOMES, 2016, p.52).

A partitura de dança marca o renascimento do espetáculo e uma nova consciência face à componente político-ideológica e ao processo social do drama estético. Evidenciando-se como uma fase de "margem" (GENNEP, 1978), tal como é entendida por Van Gennep, a partitura é marcada por uma poderosa "communitas", enquanto única fase que agrupa todas as personagens em cena, bem como por uma "antiestrutura" (TURNER, 1974), momento em que os estatutos sociais dos personagens se invertem e a separação ator/personagem se confunde. É também definida por um tempo sagrado, pois é durante a partitura de dança que se dá o momento do sacrifício e da reza coletiva por parte das mulheres. Após a partitura dá-se a fase "pós-liminar" (GENNEP, 1978), ou seja, a transformação do espetáculo e dos personagens, um momento de incorporação do renascido espetáculo com uma nova consciência. Neste sentido, a partitura evidencia uma separação do tempo e das fases da vida particularmente demarcada: entre nascimento, vida, morte e renascimento.

Já a atriz Anabela Pires, intérprete do personagem Louca, dá-nos ainda conta da sua dificuldade em controlar o tempo:

O tempo foi um aspecto pelo qual me debati inúmeras vezes, pois senti uma certa dificuldade em calcular, por exemplo, quanto tempo (duração) é que poderia estar a rir ou qual o tempo (ritmo) certo para dizer determinada sequência de palavras (Anabela Pires, mail, 05 agosto, 2016).

A ideia de que existe um tempo certo para realizar uma determinada acção apresenta analogia com uma necessidade da sociedade em controlar o tempo, medindo-o em momentos por si determinados e circunscritos, cuja expressão fundamental é assumida pelos calendários que procuram fixar um tempo sem interrupções, sem tempo morto 
(GODINHO, 2014). Contrariamente ao tempo que marca o personagem Soldado que encontrava no tempo morto e na imobilização temporal uma estratégia de expressar o seu estado de espírito resignado, uma posição face ao conflito e um método de colocação do real em cena, a Louca representa a escrita da História e a construção memorial dominante cuja temporalidade é socialmente e fortemente demarcada e construída (GODINHO, 2014). Neste sentido, a linha espaço-temporal da Louca remete-nos para a noção de lugar de memória, no sentido em que remete para uma suspensão do presente e uma manipulação da história e da memória como referenciais identitários (PERALTA, 2011):

A opção pelas diversas temporalidades em ambos os espetáculos dialoga com um entendimento do espaço cénico enquanto «lugar de memória», tal como proposto por Nora, e que evidencia uma certa instrumentalização do tempo e da memória, uma vez que "nenhum lugar de memória escapa aos seus arabescos fundadores" (NORA, 1984, p.22). Apesar de uma certa instrumentalização, continuam a emergir ligados a si acontecimentos e datas-chaves que deambulam entre o passado e o presente "sem se fixarem em tempo algum" (PERALTA, 2011, p.229), o que nos remeterá mais adiante ao conceito de «matérias-fantasma» de Avery Gordon (GORDON, 1997). Por este motivo o espaço cénico pode ser entendido como um espaço liminar, sendo "the betwixt and between" (SCHECHNER, 1986, p.7) e, neste sentido, dá lugar a uma "fronteira, a terra de ninguém, que foi zonal e se tornou linear" (GODINHO, 2014: 12). Esta é uma fronteira perigosa, sendo um "espaço marginal, periférico, descontrolado - porque fora de controlo pelos centros - torna-se zona de refúgio” (GODINHO, 2014: 12) e um lugar de resistência. É este uma soleira que se situa entre a memória e a história, entre as «memórias fortes»e as “memórias fracas" (TRAVERSO, 2012). E esta fronteira, este espaço liminar é também o lugar do corpo, da dança-teatro e da memória enquanto territórios convergentes, uma vez que o corpo possibilita minimizar distâncias espaço-temporais, compartilhar mundos e atualizar o tempo através do gesto (PORPINO, 2006).

A primeira aproximação à temática da memória é apresentada através do estudo de caso Antes que matem os elefantes e a partir das experiências dos bailarinos face ao que Porpino, parafraseando Le Breton, denominou por "memória afetiva”, ou seja, uma memória que permite a criação de "identidades provisórias" que, simultaneamente, se confundem e distinguem com o próprio intérprete (PORPINO, 2006):

Há certos momentos em que não é bem o André que está ali, mas é fruto 
de um processo muito íntimo, muito intenso, de todo o trabalho que foi feito em estúdio e de toda a pesquisa que foi feita. (...) Acho que nós passamos por vários momentos, por vários rostos, por várias vozes. Se calhar também daí as diferentes vozes que aparecem no início do espectáculo (Entrevista a André de Campos, 2016).

Se entendermos o arquivo como um depósito de documentos ou um sistema que permite a elaboração dos discursos (DIAS, 2015), o corpo é possível de ser compreendido enquanto arquivo e lugar de processos de materialização de identidades, que, no caso de André de Campos, assume várias vozes, entre a dominação e a subalternidade, uma vez que este tanto interpreta uma figura dominante quanto subalterna (SCOTT, 1990). O arquivo corresponde à história individual, encontrando-se nas margens do corpo, pelo que o arquivamento do eu é uma forma de construção de si próprio e um mecanismo de resistência, uma vez que, se considerarmos como destaca Dias, um prisioneiro que escreve um diário, compreendemos que o modo como este olha para a sua própria vida transforma a escrita a partir do momento em que sabe que o diário será lido (DIAS, 2015).

Eu sempre vi aquele sítio como um sítio que já tinha sido algo muito bom antes, ou seja, a minha relação com aquele sítio era sempre um bocadinho dali para trás e nunca dali para a frente porque eu sempre achei que dali para a frente existiria o nada e o que eu queria era um bocadinho voltar para trás, como se calhar muitas pessoas que estão naquela situação querem, não é? É um bocadinho voltar atrás no tempo (Entrevista a Francisco Rolo, 2016).

Apesar de habitarmos o mesmo espaço, todos nós tínhamos passados diferentes e tempos diferentes e, em termos de processo, todos fizemos sete escolhas diferentes sobre (Entrevista a André de Campos, 2016).

Francisco Rolo fala-nos assim de um corpo que arquiva uma versão memorial marcada pela nostalgia. O corpo, tal como denuncia o discurso do bailarino é um arquivo de distintas temporalidades onde o presente dialoga com o passado e com o futuro. Deste modo, o corpo-arquivo constitui-se como uma memória criada pelo conjunto de sistemas sensório-motores organizados pelo hábito - porções de comportamento restaurado (SCHECHNER, 2006) -, evidenciando como o corpo social determina a percepção que temos do corpo físico (DOUGLAS, 1978) e sendo uma memória presente para onde confluem diferentes tempos, tal como evidenciou o bailarino André de Campos. 
O corpo dos bailarinos/intérpretes ao recorrer aos seus arquivos transforma-se numa forma de materialização da memória, sendo que estes arquivos não correspondem apenas às memórias pessoais, mas também ao "filme-arquivo" enquanto fonte de pesquisa dos intérpretes e parte estruturante das memórias que estes assimilaram do conflito sírio:

Depois também houve alguns documentários que nos permitiram...Pelo menos para mim foi a primeira vez...Nós vimos também alguns que foi daquele site que é o «Vice», que costuma fazer alguns documentários diferentes no sentido em que...Neste caso vimos vários jornalistas que estavam a acompanhar principalmente a frente dos rebeldes e, pelo menos para mim, foi a primeira vez que tive um bocadinho do que é estar mesmo ali, tanto que o jornalista estava mesmo ao lado dos combatentes. (...) Porque de repente vê-se uma pessoa que cai, fica no chão e, de repente, ouve-se um estrondo gigante e prédios a cair, mas há momentos em que aquilo parece que quase não é real porque não há uma ligação directa entre...Não se vê tudo, não é? Vê-se sempre um lado (Entrevista a Francisco Rolo, 2016).

Sim, não era um filme, não era...Quer dizer, nós vimos mesmo pessoas a morrer, cadáveres, e não é um filme (Entrevista a André de Campos, 2016).

Sim e muitas das fotografias também que a Olga nos foi mostrando. Às vezes uma fotografia dava para explorar imensa coisa (Entrevista a Beatriz Dias, 2016).

Os filmes/documentários abordavam as histórias do conflito sírio, manejando a violência e a crueldade que o passado/presente evocam e transformando-se, assim, em "filmes-arquivo" (SOUZA, 2008). O arquivo do corpo dos bailarinos de Roriz é, deste modo, composto em grande parte por estes «filmes-arquivo» que trabalham e produzem os acontecimentos e falam de uma experiência traumática, insurgindo-se como um documento histórico socialmente construído e fonte de pesquisa histórica, do imaginário e da memória social dos intérpretes (Souza, 2008). É a partir da mobilização dos «filmesarquivo» como referenciais mnemónicos que aludem a uma «versão forte», ou seja, versões dos acontecimentos "oficiais, alimentadas pelas instituições, ou seja, os Estados" (TRAVERSO, 2012, p.71) que os bailarinos, através da dança, pretendem questionar a história. O facto de Francisco Rolo procurar ver documentários "diferentes” prende-se 
com uma tentativa de contestar as narrativas dominantes em torno do conflito sírio, procurando pelas "memórias fracas" e por um conhecimento alternativo que pudesse estruturar a sua ação em cena (TRAVERSO, 2012).

Ainda, os corpos na sua relação com os "filmes-arquivo" permitem levantar "espectros" e "matérias-fantasma" que integram o corpo dos intérpretes como forma de relação com o traumático (GORDON, 1997):

Os gritos e os clamores, os silêncios, a densidade da história da nação, as justificativas ideológicas, as forças geopolíticas, a capacidade criativa de longa data para o terror doméstico (...), a assustadora resistência política, etc. - não se somam o suficiente. Eles podem ser isolados e colocados a nu, e podem ser colocados num ímpeto político de exposição, mas parece que, nesse mesmo ato, os fantasmas retornam, exigindo um tipo diferente de conhecimento, um tipo de reconhecimento diferente. (GORDON, 1997, p.64).

O irromper dos "fantasmas" na construção da "identidade provisória” (PORPINO, 2006) dos bailarinos altera a experiência de estar no tempo e a "maneira como separamos o passado, o presente e o futuro" (GORDON, 1997: xvi). Mas esta relação com as "matérias-fantasma" é tanto ou mais relevante no universo feminino:

As mulheres estão mais numa zona de memória, de sofrimento, de apaziguamento também (Entrevista a Olga Roriz, 2016).

Portanto, o corpo muitas vezes entrava numa tensão tão grande nesta contraposição de...Lá está, da memória, do querer voltar ao passado, tentar recuperar alguma coisa que quero de novo, mas também da saturação e da frustração de ter ficado naquele sítio. E o corpo muitas vezes...Lá está, coloca-se de uma forma um pouco mais passiva, mais...Ou sentada, ou só olhar, ou de outra forma que era um movimento mais rápido, mais acelerado, mas estava sempre um bocadinho à base dessa contraposição da insistência no espaço e no voltar atrás...Dessa revolta, às vezes dessa saudade...Acabava por ser uma saudade também (Entrevista a Beatriz Dias, 2016).

A referência ao trauma associado às perdas não surge apenas como uma referência a uma instância temporal, a história do conflito sírio encontra-se transformada no corpo dos intérpretes, e, neste sentido, não é uma memória que traz de volta ao passado daquele determinado momento ou período, mas um lugar de temporalidades diversas, no qual o 
trauma é apropriado enquanto ação de transformação e libertação. A própria violência exercida sobre o corpo como dispositivo de expressar o trauma é uma forma de explorar as possibilidades do corpo e testar a resistência à dor, não numa referência aos limites do corpo das bailarinas (uma vez que são as mulheres que são indicadas de forma mais explícita pela coreógrafa como portadoras de uma memória do trauma), mas de todos os corpos envolvidos no conflito, pelo que não se trata de um corpo passivo, um mero depósito, mas sim um corpo resistente revoltado contra o biopoder e o disciplinamento (FURTADO, 2012; FOUCAULT, 1987).

É possível compreender o corpo no espetáculo Antes que matem os elefantes como um lugar que arquiva uma "versão provisória" do conflito sírio que, marcado pelas "versões fortes" e "versões fracas" (TRAVERSO, 2012) ${ }^{7}$, procura contestar as práticas memoriais hegemónicas através da libertação de «fantasmas» (GORDON, 1997), assumindo-se como micro-resistência.

Já no espectáculo Eu Sou Mediterrâneo também é evocada uma «memória afectiva» que estrutura a "identidade provisória" dos intérpretes (PORPINO, 2006). A encenadora/actriz Mónica Gomes remete-nos para o método de Stanislavski a respeito da sua interpretação no personagem Coro durante a partitura de dança:

Em termos de emoções vou buscar à minha experiência, vou buscar ao sentimento pessoal, nomeadamente o medo eu vou buscar ao sentimento de perda. Vou buscar a memórias de perda e ajuda-me a transmitir melhor o medo. Por isso há vezes acontece eu chorar, é algo que pode acontecer, pelo facto de estar a trabalhar com emoções que me são muito próximas. (...) Eu acho que quando nós tentamos reproduzir as memórias traumáticas dos outros acaba sempre por ser muito injusto e não sabemos bem o que estamos a fazer porque não podemos assumir que podemos estar na pele do outro. Nós não podemos estar na pele do outro, nós podemos estar na nossa pele e tentar imaginar um pouco do que é que poderíamos sentir se fossemos o outro. E para isso recorremos às nossas emoções piores, a momentos da nossa vida mais trágicos e tentar colar isso com o que poderá ser o sentimento (Entrevista a Mónica Gomes, 2016).

\footnotetext{
${ }^{7}$ Apropriação do conceito de Traverso (2012) de "memórias fortes" e "memórias fracas".
} 
O corpo transforma-se, deste modo, num território bio-cultural de memória que é constantemente atualizado pela própria dança/interpretação, uma vez que ao dançar/interpretar permite mobilizar o passado, criar um presente e projetar um futuro (PORPINO, 2006). A própria relação entre dança e memória é reforçada a partir do momento em que a dança acarreta em si uma memória social histórica representativa dos povos que a criaram, estando imbuída em sentidos e significados relacionados com a cultura que a originou (PORPINO, 2006). Para além disto, a dança insurge-se também como uma forma de reconstruir memórias de grupos sociais (SANTOS, 2016). O corpo é, deste modo, um texto vivo onde se inscreve a memória, sendo através do gesto que essa memória é exteriorizada chamando ao presente um tempo passado:

Quando eu faço com as mãos pelo corpo com o grito que é um bocado a libertação. É como se fosse uma limpeza, começando no peito até lá abaixo, portanto, esfrego as mãos no corpo limpando-o até empurrar o Filipe que é o «mau da fita» na dança, que eu acho que representa não só o homem todo, mas a tradição. As pessoas que estão muito agarradas aos costumes, à tradição, e não se libertam disso. Eu acho que, não é considerar que o homem, o líder islâmico, é mau, mas a tradição. Ser agarrado ao passado e viver no passado. Então aquilo, quando eu o empurro, é um «vou-me libertar do passado», a libertação do passado para continuar em frente (Entrevista a Margarida Camacho, 2016).

A intérprete/bailarina Margarida Camacho ao descrever-nos o seu desempenho no solo da partitura de dança em Eu Sou Mediterrâneo, fala-nos precisamente do tal tempo marcado pela ucronia, ou seja, "relendo sucessivamente o presente à luz do que poderia ter sido, (...) um tempo de presentismo e de história finalizada, que parece não querer construir para a frente e resgatar possíveis no universo das impossibilidades" (GODINHO, 2014b: 13). Um tempo que a antropóloga Paula Godinho define como um "tempo pegajoso" que se encontra ligado a um acontecimento ou trauma de um cataclismo (GODINHO, 2014b). A intérprete/bailarina procura, deste modo, revoltar-se contra um "mundo sem utopias" (Ibidem: 13), demonstrando-nos de que forma a dança permite "tocar o fantasma" ou seja, as complexidades do poder, a violência e a esperança, as sombras de nós próprios e da sociedade e o modo como esses «fantasmas» podem tocar a intérprete (GORDON, 1997). Margarida Camacho ao representar os sujeitos silenciados e excluídos da história chama à cena a necessidade de criar uma nova identidade cultural que olhe para o seu passado de 
forma crítica e permita ter uma perspectiva de futuro (CEDENO, 2010), pois, apesar de representar uma perda ou, neste caso, um caminho não tomado, "o fantasma também representa simultaneamente uma possibilidade futura, uma esperança" (GORDON, 1997: $64)$.

A própria noção de incorporação - embodiment - declara que a memória é um processo corporal e emocional que se enraíza em práticas e hábitos quotidianos. Neste sentido, a "memória-hábito", enquanto passado que se encontra sedimentado no corpo, apresenta-se como fundamental para o entendimento das histórias dos grupos sociais subalternos (ESPINOSA, 2007), sendo que esta "memória-hábito" é uma memória que se encontra presente em todas as performances enquanto ações que se constroem a partir de comportamentos previamente experienciados ou, como designado por Schechner, "porções de comportamento restaurado" (SCHECHNER, 2006: 4) que se apresentam como espaço privilegiado para a compreensão da memória do trauma. A atriz/bailarina demonstra-nos também de que modo a "memória afetiva" (PORPINO, 2006) enquanto «memória-hábito» guiou a sua interpretação:

Em relação ao que senti na dança, as emoções que fui buscar, (...) fui buscar à minha vida. Passei por momentos de medo, por momentos de depressão. De não me puder defender em relação aos homens. Sofri muito na mão de um Homem, calada. Mas um dia basta. O nosso corpo é nosso, é um templo, temos de o defender. Muita lágrima rolou no meu rosto, acho que a dança do mediterrâneo ajudou-me a passar algumas mágoas. Em relação às mulheres, somos especiais. Temos de lutar por nós (Margarida Camacho, mail, 12 julho, 2016).

Refere-nos Diana Tylor que o trauma e os seus efeitos pós-traumáticos continuam a manifestar-se corporalmente muito tempo depois do acontecimento que lhe deu origem, regressando e repetindo-se sob a forma de comportamentos e experiências involuntárias (TAYLOR, 2000). A intérprete Margarida Camacho demonstra-nos acima que testemunhar o trauma é relembrar algo que se quer esquecido. Foi a partir desta suposição que guiou o seu trabalho, atualizando através do gesto uma "memória fraca”, privatizada, de violência contra as mulheres e dominação masculina (BOURDIEU, 2002). A manifestação do "fantasma" (GORDON, 1997), o reverter da «memória fraca» em «memória forte» (TRAVERSO, 2012) e a exposição da «assombração», permitiu-lhe 
reivindicar por um futuro alternativo, uma vez que, como propõe Gordon, "assombrar aterroriza, mas dá-nos algo que temos de tentar por nós mesmos” (GORDON, 1997, p.134-135). Mais do que nos falar num passado, a intérprete fala-nos num futuro, pois ainda que a performance não seja uma ação involuntária, partilha com o trauma essa restauração de comportamentos experienciados previamente evocados por Schechner e, neste sentido, surge muitas vezes como transmissora de memórias traumáticas permitindo também uma ressignificação das mesmas para a construção de novos futuros. A performance é, deste modo, um agente transmissor de uma memória social que extrai e transforma imagens culturais que advêm de um determinado arquivo coletivo (TAYLOR, 2000).

Esta noção toma especial relevância se considerarmos as influências da «dançateatro» de Pina Bausch tanto no espetáculo Antes que matem os elefantes, de Olga Roriz, como em Eu Sou Mediterrâneo, de Mónica Gomes. Pina Bausch foi uma coreógrafa alemã, que por volta de 1980, fundindo a dança moderna alemã com a dança pós-moderna americana, começa a basear o seu trabalho nas histórias de vida dos bailarinos com quem trabalhava, procurando através da codificação dos gestos encontrar uma memória emocional (GARCIA, 2012), utilizando a repetição como estratégia de distanciamento da realidade. Destaque-se aqui o testemunho da intérprete/bailarina Margarida Camacho a respeito da influência da tanztheater bauscheana na sua performance em $E u$ Sou Mediterrâneo:

É assim, a dança da Pina Bausch ensinou-me a olhar em volta, em vez de falar, escutar e olhar. Porque nós encontramos o gesto numa pessoa que está simplesmente a comer ao nosso lado ou quando a pessoa está no caos da sua vida e quer sair e não consegue, há um gesto associado. Então, é olhar, observar, estudar o movimento que a pessoa está a fazer e depois pensar em como o transmitir na dança. Os principais fundamentos da Pina Bausch que utilizo... É... Ela agarrava muito na vida dos bailarinos para a «fazer» na dança. A experiência pessoal... (...), nós passamos sempre por momentos maus e bons e a dança consegue retirar desses dois coisas boas, gestos bons, e ajuda também a limpar cicatrizes, a fechá-las. E foi isso que a dança fez comigo e vai fazendo, não é? Esquecer um bocado o passado, fechando as feridas. Nós falhamos sempre, como acertamos em coisas. Agarrei em muitas falhas minhas, tentei fechar as feridas, esquecê-las e transmiti-las na dança 
(Entrevista a Margarida Camacho, 2016).

Portanto, ela [Pina Bausch] além de ir buscar movimentos a situações do quotidiano, ir também à sociedade, improvisação, caos de grupo, o corpo é usado para estimular a nostalgia, tem também técnica do ballet, usando-a sim de uma forma crítica, usa movimentos repetitivos e estranhos ... O que é eu vejo nisso? O mundo demora muito a perceber hoje em dia, nós somos um povo...não é todo, mas muitos de nós não têm cultura e a nossa mente funciona pela repetição. Então os movimentos que vou buscar à Pina Bausch são repetitivos e muito mecanizados (Margarida Camacho, mail, 12 julho, 2016).

Margarida Camacho demonstra-nos como o corpo é uma memória viva em constante recriação que permite uma ressignificação de memórias traumáticas. $\mathrm{O}$ corpo encontra-se num momento presente, pelo que a memória corporal é sempre um acontecimento do presente e só pode ser compreendida a partir do presente, até porque a memória corporal é uma memória de sensações e estas, como defende Rosely Conz, só podem ser lembradas no momento em que são sentidas (CONZ, 2012).

Dançar/interpretar entre o corpo e o lugar de memória permitido pelo corpo enquanto arquivo é atender a uma «política do chão» e lidar com "matérias-fantasma" que brotam do corpo na sua relação com o chão e com a memória (LECPECKI, 2013; GORDON, 1997). Se como salientei no segundo capítulo, as matérias-fantasma são todos os "corpos impropriamente enterrados da história" (LECPECKI, 20131 p.114), como interpretar o corpo-arquivo enquanto repositório dessas "matérias-fantasma" que, tal como o "corpo arquivo" só podem ser compreendidas a partir do presente?

O corpo do intérprete-personagem Mónica Gomes/Soldado Hasan no espectáculo Eu Sou Mediterrâneo surge como dispositivo para arquivar uma determinada memória da experiência jihadista na guerra, presente na sua gestualidade enquanto "porções de comportamento restaurado" (SCHECHNER, 2006), mas também através do seu discurso:

O Razi morreu. Quem é o Razi? Ah, não te contei? Conheci-o quando o meu líder me mandou a mim e ao Abdul de espias para a faixa de Gaza. (...) Como é que morreu? Olha, mal a manhã despertou com as primeiras orações, estava o puto na escola e zás! Levou com um projéctil em cima. Pois, não se safou. O funeral? Nós não fizemos funeral, tio, ele com embate foi logo projectado para Israel. É, passou a muralha e tudo. E 
como a terra é santa deixámo-lo lá. Se parecia em paz? Não, tio, parecia morto. E quando lá fui o mês passado já não o vi. Mas encontrei lá a mãe dele de pá na mão. Parece que consegue fugir sempre nalguns meses para vir à procura de um osso do Razi para levar para o campo de refugiados. (...) Andava a evitar mas, ontem, até lhe perguntei: Ó ti Aziza se já tem o occipital e o fémur porque é cá volta em Fevereiro? E ela respondeu-me "Quando eles me o levaram, levaram-no inteiro, por isso venho cá todos os meses. Quero que regresse como foi (GOMES, 2016, p. 107).

O discurso do personagem soldado Hasan, interpretado por Mónica Gomes, ao longo de todo o espetáculo procura problematizar a versão jihadista enquanto versão reprimida e proibida pelas instâncias políticas ocidentais, apresentando-se sob uma forma discursiva que procura humanizar o sujeito jihadista e banalizar as suas ações. Irrompendo nas sociedades ocidentais enquanto uma "versão fraca", ou seja, versões dos acontecimentos "subterrâneas, escondidas ou interditas" (TRAVERSO, 2012, p.71), e opondo-se às versões oficiais alimentadas pelos Estados ocidentais, a versão jihadista foi atirada para a clandestinidade e perpetuada como uma versão estigmatizada e criminalizada pelo discurso dominante. Neste sentido, Mónica Gomes, através do discurso do personagem, pretende alertar para o facto de que, tal como nos destaca Enzo Traverso para a questão da memória, a visibilidade e reconhecimento da versão do acontecimento depende "da força de quem a possui" (TRAVERSO, 2012, p.71-72) e demonstrar como, através de uma forte pressão por parte dos meios de propaganda jihadista e pela consequente apropriação dos média ocidentais na construção de uma versão dos acontecimentos por parte destes grupos insurgentes islâmicos, a versão jihadista passou de periférica, de "versão fraca” a "versão forte” (TRAVERSO, 2012). Também o discurso da personagem Louca como comentário à analepse "A história de Razi e o telefonema do soldado arrependido", procura evidenciar que a própria versão do Jihadismo nas sociedades ocidentais encontra-se diretamente ligada um conjunto de migrações forçadas que contribuíram para a sua transmutação em "versão forte":

Mas, quando se conquista um estatuto? Quanto será que um cadáver se torna um cadáver histórico? Quantos anos tornam um genocídio romântico? Razi, Razi... Razi, Razi, Razi... Não é um cadáver histórico. Não deu à costa na Europa, portões bonitos esses... Bonitos, bonitos, bonitos (LOUCA apud GOMES, 2016: 116). 
Através da crítica à morte do personagem Razi, o rapaz palestiniano que foi morto na Faixa de Gaza, o discurso da Louca pretende trazer à tona a versão dos "desaparecidos" e das "assombrações" (GORDON, 1997), marcados pelas "versões fracas" (TRAVERSO, 2012). Destaque-se a afirmação de Gordon relativamente ao estatuto do "desaparecido":

Desde que nós te fizemos desaparecer, tu não és nada. Enfim, ninguém se lembra de ti. Tu não existes. Uma característica constitutiva aterradora do desaparecimento é que os desaparecidos desapareceram e com eles todos os conhecimentos públicos e oficiais dos mesmos. Há um conhecimento sombrio, com certeza, e, de fato, o desaparecimento aterroriza a população de uma nação em grande parte pela incerteza que um segredo tão divulgado abrange, mas o Estado e seus vários representantes afirmam não saber nada (GORDON, 1997, p.78-79).

O "fantasma” de Razi surge na comparação e crítica à construção da versão hegemónica do acontecimento presente na criança Aylan enquanto parte de uma «versão forte» que parte de uma apropriação das vítimas do conflito pelo imaginário europeu, transformando-as num elemento constitutivo da própria identidade europeia. Este fenómeno teve origem com o irromper da vítima como sujeito privilegiado do direito da justiça internacional (um fenómeno pós Segunda Guerra Mundial), no qual a vida política depois da morte foi alargada a pessoas comuns e, assim sendo, o cadáver biológico e social insurge-se também enquanto cadáver político (ALONSO, 2014), pelo que

"En la actualidad es la propia evolución de la sociedad de los vivos la que va utilizando los cuerpos muertos como símbolos de distintas ideas políticas, casi con independencia de la propia trayectoria vital del difunto" (ALONSO, 2014, p.316).

A opção pelo fato da personagem de Razi nunca aparecer no espetáculo surge também como proposição política que tem em vista evidenciar o modo como os desaparecidos perdem a sua identidade social e política, uma vez que não há registos burocráticos, memoriais, funerais ou corpo e, neste sentido, transformam-se num meio de dominação (GORDON, 1997). A expulsão destes «fantasmas» em cena aparece também como um símbolo de que existe uma hipótese na luta pelo passado oprimido, procurando transformar as "versões fracas” numa "versão forte” (TRAVERSO, 2012) com o desígnio de estabelecer um futuro que não apague a versão dos vencidos: 
Após o reconhecimento, o passado oprimido ou o fantasma nos surpreenderá ao reconhecer a sua força animadora. Na verdade, lutar por um passado oprimido é fazer com que este venha vivo como a alavanca para o trabalho do presente: obliterar as fontes e as condições que ligam a violência do que parece terminar com o presente, acabando com essa história e estabelecendo um futuro diferente (GORDON, 1997: 65-66).

A antropóloga Paula Godinho fala-nos numa «privatização da memória», ou seja, em memórias que não podem ser recordadas em público, e por isso foram "longamente privatizadas, domesticadas, silenciadas, porque perigosas" (GODINHO, 2013, p.204). A ideia de uma privatização de uma determinada versão dos acontecimentos aparece representada no personagem Aziza, a mãe de Razi, que surge como «matéria-fantasma» (GORDON, 1997) portadora de uma memória traumática que representa todas as mães cujos filhos morreram ou desapareceram na guerra ou em consequência desta e cujo "dano infligido ou a perda sofrida por uma violência social feita no passado” (GORDON, 1997, p. xvi) permanece domesticado. O aparecimento de Aziza enquanto «matéria-fantasma», contrariamente ao trauma, implica que algo deve ser feito, é o momento em que "as pessoas que se destinam a ser invisíveis se dão a ver sem qualquer sinal de partida, (...) quando algo diferente, algo diferente de antes, parece que tem de ser feito" (GORDON, 1997, p.xvi). A desprivatização de versões dos acontecimentos, a possibilidade de as tornar públicas ou seja, o "reconhecimento do fantasma" (GORDON, 1997), como o evocou Avery Gordon, é muitas vezes impossibilitada pela dominação e obscurecida pelos consensos hegemónicos e, neste sentido, as práticas artísticas (refira-se o teatro e a dança) apresentam-se como uma possibilidade na "desprivatização de versões" (GODINHO, 2013). Este argumento é nitidamente evidenciado pela encenadora Mónica Gomes em relação ao personagem Louca:

A Louca, do lado direito, excepto durante as suas intervenções, assume uma posição estática, em cima de um pedestral, composto por uma caixa preta semelhante ao pedestrais de Museu. O museu que é por execelência o lugar de homenagem à memória, de exposição da História. Esta imagem procura remeter para a ideia de estátua e para a importância da memória e da arte como forma de inscrição na grande História, que no caso da Louca reflete a memória traumática (GOMES, 


$$
\text { 2016, p.53). }
$$

Apesar do personagem Louca falar sempre a partir do pedestal, símbolo das "versões fortes" (TRAVERSO, 2012) e da escrita da história, nalguns momentos, entre eles a crítica à história de Razi, o personagem desce do pedestal, tomando a frente do palco, sendo que este assumir da frente do palco marca os momentos em que os «fantasmas irrompem» por entre o discurso memorial reivindicando um lugar para as versões silenciadas na História oficial e um reconhecimento público da "assombração" (GORDON, 1997). A par da Louca, também o personagem Coro estabelece uma forte relação com a performance da memória traumática, uma vez que o seu corpo é a reencarnação da própria «assombração» (GORDON, 1997):

O Coro (...) vem dar voz aos mortos e mimetizar momentos passados, assumindo identidades várias, reforçando a importância do registo e da memória. (...) Também por isso o Coro está presente em grande parte do tempo, nem que seja em contra-luz, pois é a sombra e a presença constantes de um passado que ajuda a construir e reconstruir o presente e o futuro (GOMES, 2016, p.46-47).

O Coro é o melhor exemplo de como evocar os "fantasmas" através dos dramas estético-teatrais é dar visibilidade às "versões fracas" (TRAVERSO, 2012), ajudando-nos "a olhar para trás para ter a certeza de que o futuro existe, pois foi por ele que caíram os que hoje aqui lembramos" (GODINHO, 2013, p.205). Posto isto, o discurso do soldado ou a presença da Louca e do Coro não pretendem apenas expressar histórias de "fantasmas", mas consertar erros de representação e "entender as condições em que a memória foi produzida em primeiro lugar, em direção a uma contra-memória, para o futuro" (Gordon, 1997, p.22). Neste sentido, o espetáculo não só questiona as versões dominantes, como se converte num espaço alternativo para a expressão das «versões dos fracos» de grupos que foram excluídos da história oficial, numa articulação entre as «versões fracas» e o "discurso oculto" dos subordinados (SCOTT, 1990).

\section{Conclusão}

A prática memorial enquanto matéria do fazer artístico surge como um instrumento simbólico de rememoração a partir do corpo (ZILI; SANTOS, 2015). É a partir do corpo enquanto arquivo e repositório das «versões fracas» em confronto com as 
«versões fortes» (TRAVERSO, 2012) que os artistas reclamam as memórias silenciadas ou suprimidas da Guerra Civil Síria ou dos seus conflitos e traumas pessoais. Procuram, através da transposição de sentimentos relativos às versões traumáticas de um período marcado pela repressão, guerra e violência, reinterpretar os factos e encontrar um sentido de justiça, ao passo que denunciam a instrumentalização da memória em função de uma história oficial do conflito. Mais do que propor um reconhecimento dos «fantasmas», os artistas pretendem reclamar o seu não esquecimento e partir destes propor uma consciencialização em torno do conflito, pois, o "reconhecimento do assombramento é uma maneira especial de saber o que aconteceu ou está a acontecer" (GORDON, 1997, p.63). Se o conflito político, a ordem da revolução e a desordem da guerra, ou seja, o "drama social" refletido na performance, se descarrega "na sensibilidade de quem o observa com a força de uma epidemia” (ARTAUD, 1983, p.22), esta epidemia ou mise-èn-scene do «drama social» é tecida no momento em que o corpo encruzilha as teias da memória com as tramas do esquecimento. Urdida no palco da história, a mise-èn-scene do «drama social sírio» compõe-se a partir de memórias e esquecimentos, sobrepondo o passado ao presente para que se crie um futuro onde o chão se apresenta como um lugar liminar onde é possível a coexistência de diferentes formas de poder e onde a improvisação não surge apenas enquanto válvula de escape, mas compreende também um momento de antiestrutura e resistência político-cultural.

\section{Referências Bibliográficas}

ALMEIDA, Sónia V. de. "Práticas artísticas contemporâneas: imaginação e exibição da nação". Em GODINHO, Paula (coord.), Antropologia e Performance - Agir, Atuar, Exibir. Castro Verde: 100Luz, 2014, pp.99-113.

ALONSO, María García. "El descanso de los muertos. Territorios del morir y del permanecer”. In: GODINHO Paula; FONSECA, Inês; BAÍA, João, (Coords.). Resistência e/y Memória - Perspectivas Ibero-Americanas. Lisboa: IHC-FCSH/UNL, 2014, pp. 315-324.

ARAÚJO, Pedro. "Encontrando em Pina Bausch os caminhos para as memórias do corpo", Em DE JESUS, S. (Org), Anais do VIII Seminário Nacional de Pesquisa em Arte e Cultura Visual: arquivos, memorias, afetos, Goiânia: UFG/ Núcleo Editorial FAV, 2015. ARTAUD, Antonin. O Teatro e seu Duplo. São Paulo: Martins Fontes, 1983.

BARBA, Eugénio. A arte secreta do ator: dicionário de antropologia teatral. Campinas: Editora Unicamp, 1995. 
BUCCHIERI, Jean Paul. O Terceiro Corpo na escrita cénica contemporânea. Uma proposta de intervenção para a formação do intérprete. (Tese de doutorado em Motricidade Humana). Lisboa: Universidade Técnica de Lisboa, Faculdade de Motricidade Humana, 2011.

BOURDIEU, Pierre. O Poder Simbólico, Lisboa: Difel, 1989.

CEDEÑO, Janneth. "Arte y política. Entre propaganda y resistência”, Em Anuario colombiano de historia social y de la cultura, vol. 37, n. ${ }^{\circ}$ 2, Bogotá: 2010, pp. 221-243.

CERBINO, Beatriz. "Dança e memória: usos que o presente faz do passado". Em Inês Bogéa. (Org.), Primeira estação: ensaios sobre a São Paulo Companhia de Dança, 1 ed, São Paulo: Imprensa Oficial do Estado de São Paulo, v.1, 2009, pp. 33-47.

CHAGAS, Gisele. "A(s) estrada(s) para Damasco: reflexões sobre as experiências de trabalho de campo em uma sociedade do Oriente Médio”. Em Revista Antropolítica, n. 37, 2014, p. 403-423.

CONZ, Rosely. "A criação em cena: memórias, percepções e imagens que emergem do corpo que dança”, Em Revista aSPAs, vol. 2, n.1, 2012, p. 58-65.

DELEUZE, Gilles; GUATTARI, Félix. Mil Platôs. Capitalismo e Esquizofrenia, Vol.3, Rio de Janeiro: Editora 34, 1997.

DIAS, Ana Cristina. Este lugar de memória. o corpo-arquivo na dança contemporâne. (Projeto de Investigação - Doutoramento em Educação Artística), Porto: Faculdade de Belas Artes da Universidade do Porto, 2015.

ESPINOSA ARANGO, Mónica. "Memoria cultural y el continuo del genocidio: lo indígena en Colombia. Em Antípoda. Revista de Antropología y Arqueología, no5, julho-dezembro, 2007, pp.53-73.

FAZENDA, Maria José. "Corpo naturalizado experiência e discurso sobre duas formas de dança teatral americanas”, Em VALE DE ALMEIDA, Miguel. Corpo Presente: treze reflexões antropológicas sobre o corpo, Oeiras: Celta, 1996.

FOUCAULT, Michel. "Of other spaces”, Em Architecture, Mouvement, Continuité, n5. 1984, pp. 46-49.

FOUCAULT, Michel. “Os Corpos Dóceis”, Em Vigiar e punir: nascimento da prisão, tradução de Raquel Ramalhete. Petrópolis: Vozes, 1987, pp. 162-194.

FRADIQUE, Teresa. "For years, I have dreamed of a liberated Anthropology". Em GODINHO, Paula (Coord). Antropologia e Performance - Agir, Atuar, Exibir. Castro Verde: 100Luz, 2012, pp. 9-24.

FURTADO, Beatriz. "Corpo-Arquivo nas obras fílmicas de Sigalit Landau e Marina Abramovic", Em O corpo, lugar da memória (Texto apresentado na Bienal de Dança de Fortaleza), 2012. 
GARCIA, Cristina Freire. Memória e Representação (através) do Corpo. (Projcto de Mestrado em Ciências da Comunicação - Especialização em Comunicação e Artes), Lisboa: Faculdade de Ciências Sociais e Humanas da Universidade Nova de Lisboa, 2012.

GODINHO, Paula. Usos da Memória e práticas do património. Alguns trilhos e muitas perplexidades. IN: GODINHO, Paula (Coord). Usos da memória e práticas do património. Lisboa: Colibri, 2012.

GODINHO, Paula. "Agir, atuar, exibir. Antropologia e Performance, uma introdução" e "A violência do olvido e os usos políticos do passado: lugares de memória, tempo liminar e drama social”, Em GODINHO, Paula. (Coord). Antropologia e Performance - Agir, Atuar, Exibir. Castro Verde: 100Luz, 2014a, pp. 9-24; 193-213.

GODINHO, Paula, "Tempo, memória e resistência", Em GODINHO Paula, FONSECA, Inês; BAÍA, João, (Coords.). Resistência e/y Memória - Perspectivas Ibero-Americanas [Documento electrónico], Lisboa: IHC-FCSH/UNL: 2014b, pp. 5-15.

GOMES, Mónica. Eu Sou Mediterrâneo: um espectáculo sobre a banalidade do mal. Dissertação (Mestrado). Lisboa: Escola Superior de Teatro e Cinema, 2016.

GORDON, Avery. Ghostly matters. Minneapolis: University of Minnesota Press, 1997.

GREBLER, Maria Albertina Silva. "Bausch e Brecht: a dança-teatro e o drama épico”, Em II Seminário e Mostra Nacional de Dança Teatro, Viçosa, 2010.

HALBWACHS, Maurice. A memória coletiva, São Paulo: Vértice, 1990.

LEPECKI, André. “Coreopolítica e coreopolícia”, Em ILHA, v. 13, n. 1, 2011, p. 41-60, jan./jun.

"Planos de composição: dança, política e movimento". Em RAPOSO et al, A terra do não-lugar. Diálogos entre antropologia e performance. Florianópolis: editora UFSC, 2013, p. $109-120$.

LOPES, Beth. “A performance da memória”, Em Revista Sala Preta, vol. 9, 2009, pp.135145.

LOWENTHAL, David (1995), "Como conhecemos o passado", Em The past is a foreign country. 7a Edição. [Trad. Lúcia Haddad], Cambridge: Cambrigde University Press, 1995.

NORA, Pierre. "Entre memória e história - a problemática dos lugares", Em Les lieux de mémoire, I La République. Paris: Gallimard, 1984.

PINTO COELHO, Sílvia Tengner Barros. Corpo, Imagem e Pensamento Coreográfico: da pesquisa coreográfica contemporânea enquanto discurso: os exemplos de Lisa Nelson, Mark Tompkins, Olga Mesa e João Fiadeiro (Tese de Doutoramento em Ciências da Comunicação - Comunicação e Artes), Lisboa: Faculdade de Ciências Sociais e Humanas, Universidade Nova de Lisboa, 2016. 
PORPINO, Karenine. “Corpo, Dança e Memória: territórios convergentes”, Em VI Congresso de pesquisa e pós-graduação em artes cénicas. Natal:Universidade Federal do Rio Grande do Norte, 2010.

PRINZAC, Mônica. Performance da dor. (Dissertação de Mestrado em Teatro do Centro de Letras e Artes). Rio de Janeiro: Centro de Letras e Artes, Universidade do Rio de Janeiro, Brasil, 2005.

SANTOS, Cláudio Félix dos et al. "A memória escrita no ar: dança enquanto memórias das experiências humanas", Em X Seminário Nacional do HISTEDBR. Contribuições para a história e historiografia da educação brasileira. Unicamp, 2016.

SCHECHNER, Richard. "Victor Turner's Last Adventure”. Em: TURNER, Victor. The Anthropology of Performance, NY: PAJ Publications, 1986.

SCOTT, James. Los Dominados y El Arte de la Resistencia, Barcelona: ERA, 2000.

SOUZA, Maria Luiza. "Cinema, ditadura e memória: questões para uma antropologia do cinema narrativo", Em 26. Reunião Brasileira de Antropologia, Anais 26 RBA, Porto Seguro, Bahia, Brasil, 2008.

TAYLOR, Diana. "El espectáculo de la memoria: trauma, performance y política". Em Teatro al Sur, no 15, 2000, pp. 33-40.

TRAVERSO, Enzo. "O Tempo e a força”. Em O passado, modos de usar: história, memória e política, Lisboa: Edições Unipop, 2012, pp. 55-71.

TURNER, Victor. O processo ritual: estrutura e anti-estrutura, Petrópolis: Vozes, 1974.

VAN GENNEP, Arnold; Os ritos de passagem. Petrópolis: Vozes, 1978.

VIER MUNHOZ, Angélica. "Entre corpo e lugar: dançar o chão”. Em ALEGRAR,16, 2015.

ZILI, Gabriela; SANTOS, Carlos. "A produção artística através das memórias políticas: uma elaboração de novas memórias”, Em XIV Seminário de História da Arte, n5, vol.14, 2015, pp. 01-14.

autora Sílvia Alexandra Raposo

É antropóloga, dramaturga e escritora portuguesa, com licenciatura e mestrado em Antropologia. Atualmente é doutoranda vinculada ao Centro em Rede de Investigação em Antropologia, no polo da Universidade Nova de Lisboa.

Recebido em: 01/08/2017

Aceito para publicação em: 07/11/2018 